\title{
Shiga toxin-producing Escherichia coli 0104:H4: An emerging important pathogen in food safety
}

\author{
CUI YuJun ${ }^{1,2}$, LI DongFang ${ }^{2} \&$ YANG RuiFu $^{1,2^{*}}$ \\ ${ }^{1}$ State Key Laboratory of Pathogen and Biosecurity, Beijing Institute of Microbiology and Epidemiology, Beijing 100071, China; \\ ${ }^{2}$ BGI-Shenzhen, Shenzhen 518083, China
}

Received October 8, 2011; accepted February 29, 2012; published online February 1, 2013

In 2011, Shiga toxin-producing Escherichia coli O104:H4 resulted in a large outbreak of bloody diarrhea and hemolytic uremic syndrome (HUS) in Germany and 15 other countries in Europe and North America. This event raised a serious public health crisis and caused more than two billion US dollars in economic losses. In this review, we describe the classification of $E$. coli, the Germany outbreak, and the characteristics and epidemical source-tracing of the causative agent. We also discuss the genomics analysis of the outbreak organism and propose an open-source genomics analysis as a new strategy in combating the emerging infectious diseases.

Shiga toxin-producing, Escherichia coli, O104:H4, hemolytic uremic syndrome, outbreak, open-source genomic analysis

Citation: $\quad$ Cui Y J, Li D F,Yang R F. Shiga toxin-producing Escherichia coli O104: H4: An emerging important pathogen in food safety. Chin Sci Bull, 2013, 58: 1625-1631, doi: 10.1007/s11434-012-5613-1

The large outbreak of food poisoning caused by the Shiga toxin-producing Escherichia coli O104:H4 in Germany from May to July, 2011 [1] threw the public health agencies into an embarrassing situation. Many strains of $E$. coli, with varying virulence, have caused many outbreaks in history [2-10] and this bacterium is one of the most studied pathogens. However, effective measures of identification, prevention, and treatment were insufficient during the whole outbreak process. In the past, Shiga toxin-producing and sorbitol-negative $E$. coli O157:H7 was the main agent responsible for the majority of outbreaks. However, Shiga toxin-producing and sorbitolfermenting $E$. coli strains other than O157:H7 have recently emerged, with the ability to cause outbreaks [11-23]. The 2011 Germany outbreak of the O104:H4 has brought renewed attention to this specific category of $E$. coli.

\section{Classification of $E$. coli}

E. coli is a Gram-negative, rod-shaped bacterium, which is

\footnotetext{
*Corresponding author (email: yangruifu@ genomics.org.cn)
}

usually serotyped by the somatic (cell wall) "O" antigen and the flagella " $\mathrm{H}$ " antigen. Capsular " $\mathrm{K}$ " antigen has also been employed to serotype this bacterium. Over 700 serotypes of the bacterium $E$. coli have been identified, with $\mathrm{O} 157: \mathrm{H} 7$ being the most notorious. Most of these serotypes are non-pathogenic facultative bacteria in the human intestine, in plants, and in the environment. A few E. coli strains, however, have developed the ability to cause three types of disease in humans: intestinal diseases (gastroenteritis), urinary tract infections (UTI), and neonatal meningitis. The distribution and expression of an array of virulence determinants, including adhesins, invasins, toxins, etc., and abilities to withstand host defenses, determine the pathogenicity of a particular strain of E. coli (Table 1). Pathogenic E. coli can be divided further according to the known pathogenesis, namely, diarrheagenic E. coli that caused enteric disease, including ETEC (enterotoxigenic E. coli), EIEC (enteroinvasive E. coli), EHEC (enterohemorrhagic E. coli), EPEC (enteropathogenic E. coli), EAEC (enteroaggregative $E$. coli), and DAEC (diffusely adherent E. coli) [24]; uropathogenic E. coli (UPEC) that caused urinary tract infection [25]; and neonatal meningitis-associated E. coli (NMEC) 
Table 1 Selected virulence factors produced by different pathovars of $E$. coli

\begin{tabular}{|c|c|c|c|c|}
\hline Pathovar & Adhesins & Invasive ability and related factors & Toxins or other virulence determinants & Symptoms \\
\hline ETEC & $\begin{array}{l}\text { fimbrial adhesins e.g. CFA I, } \\
\text { CFAII, K88, K99 }\end{array}$ & no & $\begin{array}{l}\text { heat-labile enterotoxin (LT); } \\
\text { heat stable toxin (ST) }\end{array}$ & $\begin{array}{l}\text { watery diarrhea in infants and } \\
\text { travelers; no inflammation, no } \\
\text { fever }\end{array}$ \\
\hline EIEC & $\begin{array}{l}\text { nonfimbrial adhesins, possibly } \\
\text { outer membrane protein }\end{array}$ & $\begin{array}{l}\text { yes } \\
\text { An invasion-related plasmid pInv } \\
\text { carrying the mxi and spa loci, which } \\
\text { encodes a type III secretion system. }\end{array}$ & $\begin{array}{l}\text { No specific toxin was identified. } \\
\text { However, a } 63-\mathrm{kD} \text { protein encoded } \\
\text { by a plasmid-carrying gene sen was } \\
\text { proven related to the enterotoxic } \\
\text { activity. }\end{array}$ & $\begin{array}{l}\text { dysentery-like diarrhea (mucous, } \\
\text { blood), severe inflammation, fever }\end{array}$ \\
\hline EPEC & $\begin{array}{l}\text { nonfimbrial adhesin (intimin) } \\
\text { bundle-forming pilus (BFP) }\end{array}$ & yes, but lower than Shigella or EIEC & $\begin{array}{l}\text { some strains to produce Shiga-like } \\
\text { toxin; } \\
\text { ST-like toxin (EAST1); } \\
\text { Four secreted proteins, EspA ( } 25 \\
\mathrm{kD}) \text {, EspB ( } 38 \mathrm{kD} \text {; formerly called } \\
\text { EaeB), and EspD }(40 \mathrm{kD}) \text {, are essen- } \\
\text { tial for the A/E phenotype. }\end{array}$ & $\begin{array}{l}\text { usually infantile diarrhea; watery } \\
\text { diarrhea with blood, some in- } \\
\text { flammation, no fever; symptoms } \\
\text { probably result mainly from } \\
\text { invasion rather than toxigenesis }\end{array}$ \\
\hline EAEC & $\begin{array}{l}\text { aggregative adherence } \\
\text { fimbriae (AAF) }\end{array}$ & not determined & $\begin{array}{l}\text { EAST1; } \\
\text { Hemolysin; } \\
\text { Two possible cytotoxins, } 108-\mathrm{kD} \\
\text { and } 120-\mathrm{kD} \text { proteins, were also iden- } \\
\text { tified. }\end{array}$ & $\begin{array}{l}\text { persistent diarrhea in young } \\
\text { children without inflammation or } \\
\text { fever }\end{array}$ \\
\hline DAEC & $\begin{array}{l}\text { a surface fimbria } \\
\text { a } 100-\mathrm{kDa} \text { OMP }\end{array}$ & not determined & Not determined & $\begin{array}{l}\text { Not epidemiologically defined } \\
\text { because some strains could not } \\
\text { elicit diarrhea upon human vol- } \\
\text { unteer challenge and no out- } \\
\text { breaks of DAEC-associated ill- } \\
\text { ness have been documented to } \\
\text { date. }\end{array}$ \\
\hline EHEC & $\begin{array}{l}\text { Intimin; } \\
\text { E. coli common pilus (ECP); } \\
\text { haemorrhagic coli pilus (HCP) }\end{array}$ & yes, but lower than Shigella or EIEC & $\begin{array}{l}\text { Shiga toxins (also called verotoxins); } \\
\text { EAST1; } \\
\text { Enterohemolysin }\end{array}$ & $\begin{array}{l}\text { pediatric diarrhea, copious bloody } \\
\text { discharge (hemorrhagic colitis), } \\
\text { intense inflammatory response, } \\
\text { may be complicated by hemolytic } \\
\text { uremia }\end{array}$ \\
\hline UPEC & $\begin{array}{l}\text { P fimbria (or pyelonephritis- } \\
\text { associated pili [PAP]); } \\
\text { Type } 1 \text { fimbriae }\end{array}$ & $\begin{array}{l}\text { yes } \\
\text { fimbrial adhesin } H(\text { FimH), which is } \\
\text { found at the tip of the type } 1 \text { fimbriae. }\end{array}$ & $\begin{array}{l}\alpha \text {-hemolysin (HlyA); } \\
\text { vacuolating autotransporter toxin } \\
\text { (Vat); } \\
\text { Siderophores for iron acquisition }\end{array}$ & urinary tract infections (UTI) \\
\hline NMEC & $\begin{array}{l}\text { outer membrane protein A } \\
\text { (OmpA); } \\
\text { Type } 1 \text { fimbriae }\end{array}$ & $\begin{array}{l}\text { yes } \\
\text { Cytotoxic necrotizing factor } 1 \text { (CNF1); } \\
\text { OmpA; } \\
\text { Type } 1 \text { fimbriae }\end{array}$ & $\begin{array}{l}\text { Endotoxin; } \\
\text { K-1 antigen; } \\
\text { Chu haem transport system }\end{array}$ & Neonatal meningitis \\
\hline
\end{tabular}

that caused human neonatal meningitis [26]. As molecular genetics technology has advanced in recent years, there has been increasing interest in extending the classification of $E$. coli from phenotype to genotype. E. coli was divided into five genetic distinct phylogroups, namely, A, B1, B2, D, and E, through multi-locus enzyme electrophoresis (MLEE) [27]. Furthermore, Shigella, a genus of strains that cause dysentery, was proven genetically closely related to E. coli and actually can be regarded as another phylogroup of $E$. coli $[28,29]$. The robustness of phylogroups was validated separately by the multi-locus sequence typing (MLST) analysis [30] and phylogenomics research based on wholegenome sequencing technology [31].

\section{Outbreak of Shiga toxin-producing E. coli 0104:H4}

As early as 2001, a hemolytic uremic syndrome-associated enterohemorrhagic E. coli (HUSEC) with serotype O104:H4, HUSEC041 (also designated as 01-09591), was isolated in Germany from patients [32]. This strain could produce Shigatoxin 2 and belonged to sequence type 678, which was same as the 2011 outbreak strains [33]. Unfortunately, no detailed report exists on the symptoms of the patients from whom this strain was isolated. The first complete report on a case of hemolytic uremic syndrome (HUS) caused by E. coli O104:H4 was from Korea in 2006 [34], on a 29-year-old healthy woman. The bacteria were thought to have been transmitted through the consumption of hamburgers; however, the exact origin of the pathogen was not clear. The patient presented with bloody diarrhea, abdominal pain, hemolytic anemia, thrombocytopenia, and acute renal failure. The E. coli O104:H4 was isolated from her stool specimen. Fortunately, the patient finally recovered with obvious sequelae through timely proper treatment with plasmapheresis and hemodialysis for three weeks.

From May 1 to July 26, 2011, an unusual outbreak of 
diarrhea with HUS hit Germany and spread to other European countries. The outbreak then spread to the United States and Canada. In total, there were 4075 cases reported: 3935 in Germany and 140 from other countries according to a WHO report (Shiga toxin-producing E. coli (STEC): Update on outbreak in the EU (27 July 2011, 11:00), http:// www.euro.who.int/en/what-we-do/health-topics/emergencies/ international-health-regulations/news/news/2011/07/outbreaks-of-e.-coli-o104h4-infection-update-30, accessed by Sept 16, 2011). The cases recorded in Germany were 3078 EHEC and 857 HUS cases, with 48 dead; in other countries, there were 89 EHEC and 51 HUS cases. The Robert Koch Institute (RKI), the university medical center HamburgEppendorf, and the health department of the Hamburg northern district reported that the epidemic profile of this outbreak was caused by Shiga toxin-producing $E$. coli O104:H4 [35]. This outbreak is unusual because majority of the cases $(89 \%)$ were with adults (median age, 43 years) with a preponderance of cases $(68 \%)$ occurring in women. In addition, HUS developed in a quarter of the symptomatic outbreak cases, contradicting a previous report that HUS usually develops in children under five years old [24]. The infection caused by $\mathrm{O} 104$ :H4 had an unusually long incubation period (eight days on average) than that of conventional $E$. coli infections (three days on average), which confused clinicians and delayed timely recognition.

\section{The pathogen of $E$. coli $0104: \mathrm{H} 4$}

As mentioned above, O104: $\mathrm{H} 4$ was found ten years ago in 2001 in Germany and five years ago in 2006 in Korea $[32,34]$, indicating that this bacterium is not a newlyemerged pathogen. Nevertheless, the extensive characterization of this pathogen only began in 2011 due to the widespread outbreak $[33,36]$. The outbreak strain turned out to be an unusual combination of the pathogenic features of "stacked brick" aggregation of adherence to HEp2-cells in culture, which is typical of EAEC, and of Shiga toxin production, which is typical of EHEC [36]. Compared with HUSEC041 that was isolated in 2001, the outbreak strain acquired an extended-spectrum $\beta$-lactamase phenotype as well as resistance to many other types of antibiotics [33]. Detection of other virulence-associated genes characterizing both EAEC and EHEC indicated that the virulence backbone of the outbreak strain should be EAEC. In addition, bacteriophage-encoding Shiga toxin 2 was acquired from EHEC or an unknown environment, along with other antibiotics-resistant genes from unknown sources [33,36-38].

\section{Epidemical source-tracing of Shiga toxin- producing $E$. coli $0104: H 4$}

After recognizing the unusual outbreak, German scientists scrambled to find its source. Local authorities in Hamburg announced on May 26 that they had isolated the EHEC bacteria from four cucumbers imported from Spain (http:// news.sciencemag.org/scienceinsider/2011/05/cucumbers-maybe-culprit-in-mass.html, accessed by Sept 16, 2011). However, it was confirmed five days later that the EHEC isolated from Spanish cucumbers was not same as the outbreak strain; the mistake led to a loss of millions of Euros from Spanish agriculture. German scientists then conducted a series of epidemiological investigations for determining the source of the outbreak strain. Bean sprouts were suspected as the source (http://www.mzh.government.bg/MZH/Libraries/ Actual2/E_coli_23_July_ENG_corr.sflb.ashx, accessed by Sept 16, 2011). Although several outbreaks of Salmonella and E. coli O157:H7 infections had been reported to be associated with raw seed sprouts [39], no O104:H4 strain had been isolated from any sprout. It need further works to confirm if 2011's outbreak was caused by contaminated sprouts or bean seed. After a cluster of patients with bloody diarrhea was reported in Bordeaux, France, the European food safety authority (EFSA) conducted a source-tracing analysis, revealing that sprouts of fenugreek were suspected as a contamination source (www.efsa.europa.eu/en/supporting/ doc/176e.pdf, accessed by Sept 16, 2011). When the sourcetracing information from both French and German outbreaks was analyzed together, the fenugreek seeds imported from Egypt were the most likely common source. Although extensive epidemiological investigations were implemented, there had previously been no bacterial evidence to confirm any food as the source of E. coli outbreak in Germany.

\section{Genome sequencing and comparative genomics of $0104: \mathrm{H} 4$}

Concurrent with the epidemiological investigation, scientists around the world rushed to sequence the whole genome of the outbreak strains to understand their phenotypic and virulent features, as well as acquire the strain-specific sequences using in designation of PCR diagnostic primers [37,38,40-42]. We sequenced one outbreak strain, TY2482, isolated by the University Medical Center Hamburg-Eppendorf during the early phase of the outbreak from a 16-yearold female patient suffering from hemorrhagic enterocolitis. We deciphered the whole genome sequences of the strain within five days after receiving the DNA sample using the Ion Torrent Personal Genome Machine, which is a semiconductor-based third-generation sequencing platform. About a week later, the sequencing data from the Illumina HiSeq 2000 sequencing system was acquired and used to improve the assembly results. Finally, one chromosome and three plasmids were assembled and identified from this strain [37].

To identify the phylogenetic position of the TY2482, we selected 30 whole genome sequences of $E$. coli strains 
(including 12 avirulent strains and 18 that belong to five different pathotypes, which can be used to represent the diversity of the species) and eight Shigella strains (Table $\mathrm{S} 1)$. We used this data to build the maximum likelihood tree based on 177223 whole genome-wide SNPs. Intriguingly, TY2482 is most closely related with a Central Africa-isolated EAEC strain, 55989 although clinical symptoms were reported similar to those caused by EHEC strains [31]. According to the phylogenetic tree, four O157 EHEC strains belong in a different phylogroup (group E) from TY2482, three non-O157 EHEC strains and TY2482 belong to the same group (B1) but still have long genetic distance (Figure 1). Therefore, the strain that caused the outbreak should be defined as EAEC-lineage rather than EHEC in terms of phylogeny.

When we employed the seven conserved housekeeping genes of this new Shiga toxin-producing EAEC strain to compare with the database (http://mlst.ucc.ie/mlst/dbs/Ecoli) of more than $3800 \mathrm{E}$. coli strains, we found that the outbreak strain is identical to strain 01-09591, which was isolated 10 years ago in Germany [32]. In addition, TY2482 and 01-09591 have the same profiles in 12 virulence/fitness genes, whereas the Shiga toxin-producing gene and tellurite-resistance-genes were not detected in 55989. These findings imply that the 01-09591 is closer to the current outbreak strain. Although the genome sequence of the strain 01-09591 indicated that it was different from the 2011 outbreak strain in terms of plasmid content and fimbrial genes [41], the fact that the German-origin O104:H4 isolate is closely related to the Germany outbreak strain is still of scientific interest.

The EAEC strain 55989 was only associated with persistent diarrhea, whereas TY2482 can cause HUS [37]. We carried out whole genome comparative studies between the two strains to explore the possible genetic mechanisms of different virulence phenotypes. Approximately 96\% chromosomal regions in strain 55989 can be covered by chromosome sequence of TY2482 with extensive synteny conservation along the chromosome, and only $6 \%$ chromosome sequence of TY2482 was strain-specific, indicating highly consistent genomic content between the two strains. Only one among the three TY2482 plasmids reveals similarity with 55989, but carried a rare type of aggregative adherence fimbria gene cluster, $\mathrm{AAF} / \mathrm{I}$, rather than the $\mathrm{AAF} / \mathrm{III}$ in

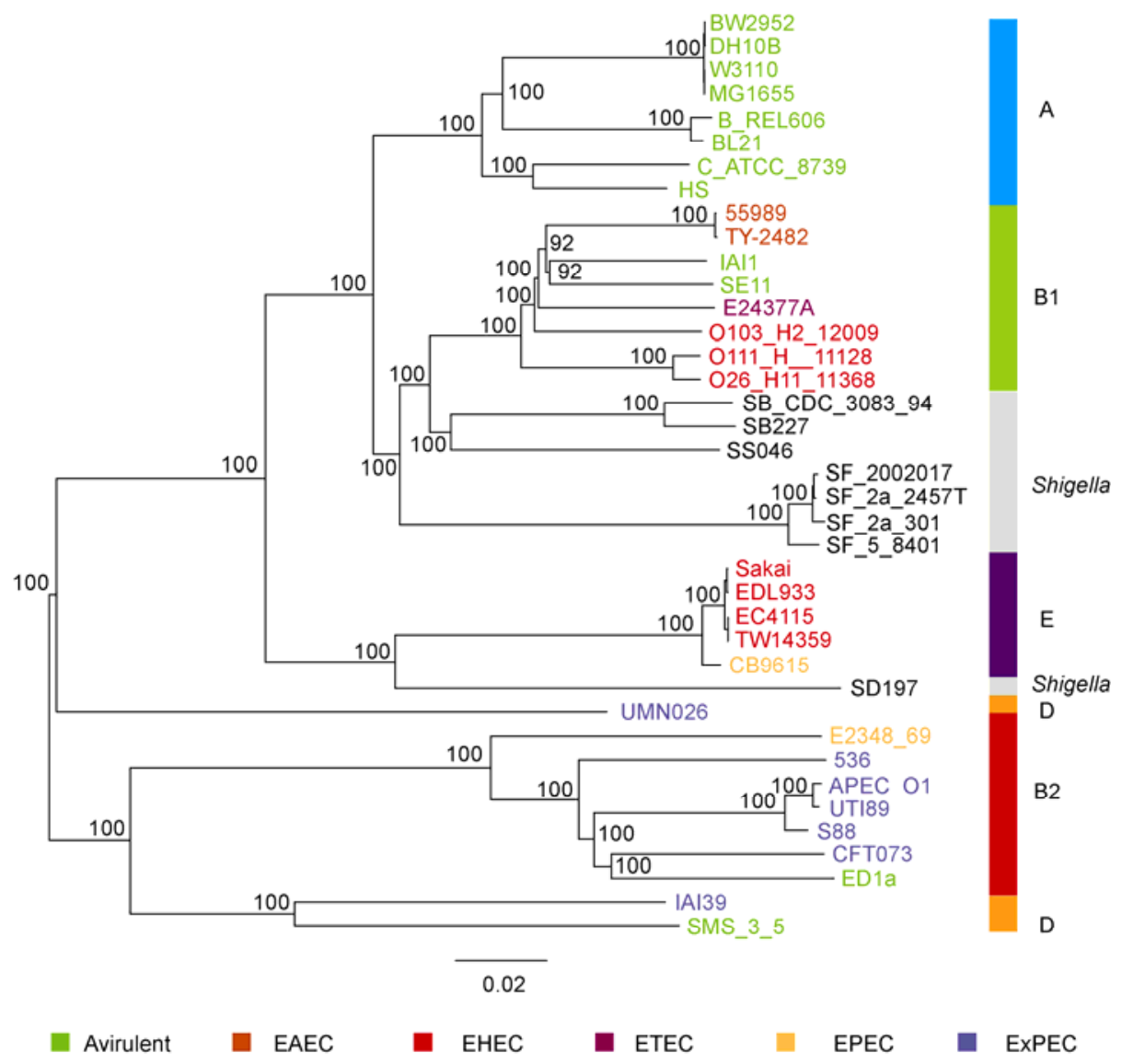

Figure 1 Phylogenetic tree of 39 E. coli_Shigella strains based on whole genome wide SNPs. The maximum likelihood phylogeny was built using PHYML, with 1000 repeat bootstrap tests. The numbers near internal nodes indicate the percentage of the supported bootstrap value. The scale bar represents substitutions per SNP site. The colored bar at the right of the tree represents different phylogroups. The tip names were colored according to pathovars as per the legend listed below the tree. 
55989. In the case of the other two plasmids absent in 55989, the larger of these encodes a CTX-M-15 extendedspectrum beta-lactamase and is highly homologous with the pEC plasmid identified in other E. coli strains [43]. The smaller of these is a selfish plasmid carrying only two genes and one encoding DNA replication protein. On TY2482specific chromosomal regions, we identified 553 genes, 316 of which are clustered and were annotated as seven regions of difference (RODs). The RODs and the plasmids encoded a variety of virulent determinants, antibiotic resistance, and fitness associated proteins; I-ROD2 (I-ROD, region of difference involving a insertion) in particular is a prophage that contains the stx 2 gene for Shiga toxin, indicating that horizontal gene transfer events play important roles for high virulence and survival of TY2482 [37].

The outbreak strain presented EHEC pathotypes, thus, we investigated the genome content of TY2482 for possible EHEC virulent determinants. There are 136 previously reported EHEC virulence-related genes [44] in TY2482 genome (Table S2), only 19 of which are present in most EHEC strains and less prevalent among non-EHEC strains (Fisher exact test, $P<0.01$, Table 2). Two genes, st 2 and lom, could only be found in EHEC strains and TY2482. The gene lom is located on the stx2-bearing phage and involved in E. coli adhesion [45]. Notably, four other adhesion-related genes present in TY2482 were also identified in almost all EHEC strains, stressing the utmost importance of adhesion for EHEC pathogenicity. However, the most prevalent pathogenicity island in typical EHEC strains, LEE (locus of enterocyte effacement), which encodes the Type III secretion system responsible for attaching and effacing lesions in the intestine, thought to facilitate the translocation of the Shiga-toxin into the bloodstream of the host [24], was not detected in the TY2482. It was supposed that the enteroaggregative virulence factors in the outbreak strain may compensate for properties of LEE, resulting in similar or even increased virulence. For example, iha could promote the adherence of $E$. coli to the bovine-originated epithelial cells [46]. Further, the production of fimbria I gene cluster-encoded fimbriae leads to biofilm formation, which also contributes to the stable adherence of $E$. coli cells to human epithelia $[47,48]$. Further experimentation is needed to test if and how the unusual combination of EAEC-related adherence mechanisms with st 2 and additional EHEC-derived virulence determinants contribute to the shift in populations at risk (i.e. the preferential infection of women) and the specific clinical course of the disease.

\section{Open-source genomics}

We developed a new strategy, open-source genomics [37], for combating emerging infectious diseases, in addition to helping us understand the phenotypic and pathogenic features of the outbreak strain, and developing a rapid nucleic acid-based diagnostic method [42] through rapid whole genome sequencing analysis. In the past, scientists usually release their genome sequencing data after their paper is

Table 2 The EHEC-prevalent virulence genes in TY2482

\begin{tabular}{|c|c|c|c|c|}
\hline Gene ID & Product & $\operatorname{EHEC}(7)^{*}$ & Non-EHEC(31)* & $P$ value** \\
\hline \multicolumn{5}{|l|}{ Afimbrial adhesins } \\
\hline GL004286 & AidA-I adhesin- like protein & 7 & 5 & $6.28 \times 10^{-5}$ \\
\hline GL005117 & Iha adhesion & 6 & 7 & $3.54 \times 10^{-3}$ \\
\hline GL003010 & predicted adhesin & 7 & 10 & $1.54 \times 10^{-3}$ \\
\hline pTY2GL0061 & adherence factor, Efa1 homolog & 7 & 13 & $8.66 \times 10^{-3}$ \\
\hline \multicolumn{5}{|c|}{ Genes the confer resistance to the host defense response } \\
\hline GL005073 & Lom type 2 & 5 & 0 & $4.18 \times 10^{-5}$ \\
\hline \multicolumn{5}{|c|}{ Toxins and their activation and secretion } \\
\hline GL005048-9 & Shiga toxin 2 subunit $\mathrm{AB}$ & 6 & 0 & $2.54 \times 10^{-6}$ \\
\hline \multicolumn{5}{|l|}{ Regulators } \\
\hline GL002293 & PchD & 5 & 4 & $4.25 \times 10^{-3}$ \\
\hline GL002123 & EtrA & 7 & 6 & $1.36 \times 10^{-4}$ \\
\hline \multicolumn{5}{|c|}{ T3SS and effector homologues } \\
\hline GL000529 & EspR1 & 7 & 10 & $1.54 \times 10^{-3}$ \\
\hline GL003969 & EspX1 & 7 & 6 & $1.36 \times 10^{-4}$ \\
\hline GL002119-29 & ETT2 & 6 & 5 & $1.01 \times 10^{-3}$ \\
\hline
\end{tabular}

* The number in parentheses indicates the number of EHEC or Non-EHEC strains used in analysis. ** Two genes with low $P$-value harbored in two multigene clusters respectively; as most genes in the clusters are frequently observed in both EHEC and EAEC strains, these two genes were excluded from this table. 
accepted for publication. For our strategy, we released the genome data, including raw data, into the public domain under a Creative Commons 0 license, as soon the preliminary sequences were obtained. This elicited a burst of crowd-sourced, curiosity-driven analyses carried out by bioinformaticians on four continents, which provided public society opportunities to propose the possible origins, identification methods, and reasons for the virulence and antibiotic-resistance of the outbreak strain. (https://github.com/ ehec-outbreak-crowdsourced/BGI-data-analysis/wiki). We then took advantage of intellectual scientists around the world to improve our analysis. This type of internet-connected collaboration based on common interests could play key roles in future combat against infectious diseases.

The Germany O104:H4 outbreak is over, but the war between humans and pathogens never ends. As long as rapid urbanization, environmental change, the expansion of human activity, the rapid development of transportation, and the increasing number poor and hungry people in numerous regions around the world are still problems for us to tackle, pathogens will find more chances to interact with humans, and new infectious diseases will be continually emerging. Therefore, we should take advantage of new advances in technology, new developments in strategy, and our network of intellectuals around the world to develop new mechanisms to achieve victory in the battle against infectious diseases.

This work was supported by the National Basic Research Program of China (2009CB522600) and Shenzhen Biological Industry Development Special Foundation-Basic Research Key Projects (JC201005250088A).

1 Pennington H. Escherichia coli O104, Germany 2011. Lancet Infect Dis, 2011, 11: 652-653

2 Bettelheim K A. Escherichia coli O157 outbreak in Japan: Lessons for Australia. Aust Vet J, 1997, 75: 108

3 Cody S H, Glynn M K, Farrar J A, et al. An outbreak of Escherichia coli O157:H7 infection from unpasteurized commercial apple juice. Ann Intern Med, 1999, 130: 202-209

4 Pebody R G, Furtado C, Rojas A, et al. An international outbreak of Vero cytotoxin-producing Escherichia coli 0157 infection amongst tourists; a challenge for the European infectious disease surveillance network. Epidemiol Infect, 1999, 123: 217-223

5 Watanabe Y, Ozasa K, Mermin J H, et al. Factory outbreak of Escherichia coli O157:H7 infection in Japan. Emerg Infect Dis, 1999, 5: $424-428$

6 Ongoing Multistate Outbreak of Escherichia coli serotype O157:H7 Infections Associated with Consumption of Fresh Spinach-United States, September 2006. MMWR Morb Mortal Wkly Rep, 2006, 55: 1045-1046

7 Manago S, Kishikawa K, Tokunaga $\mathrm{H}$, et al. Outbreak of enterohemorrhagic Escherichia coli $\mathrm{O} 157$ attributed to a grilled-meat restaurant. Jpn J Infect Dis, 2006, 59: 407-408

8 Friesema I, Sigmundsdottir G, van der Zwaluw K, et al. An international outbreak of Shiga toxin-producing Escherichia coli O157 infection due to lettuce, September-October 2007. Euro Surveill, 2008, 13

9 Kotewicz M L, Mammel M K, LeClerc J E, et al. Optical mapping and 454 sequencing of Escherichia coli $\mathrm{O} 157: \mathrm{H} 7$ isolates linked to the US 2006 spinach-associated outbreak. Microbiology, 2008, 154: 3518-3528
10 Watanabe K, Murayama A, Kogure N, et al. An outbreak of food poisoning due to enterohemorrhagic Escherichia coli O157 in Niigata, Japan. Jpn J Infect Dis, 2010, 63: 146-147

11 Community outbreak of hemolytic uremic syndrome attributable to Escherichia coli O111:NM-South Australia 1995. MMWR Morb Mortal Wkly Rep, 1995, 44: 550-551, 557-558

12 Outbreak of Acute Gastroenteritis Attributable to Escherichia coli Serotype O104:H21-Helena, Montana, 1994. MMWR Morb Mortal Wkly Rep, 1995, 44: 501-503

13 McMaster C, Roch E A, Willshaw G A, et al. Verocytotoxinproducing Escherichia coli serotype O26:H11 outbreak in an Irish creche. Eur J Clin Microbiol Infect Dis, 2001, 20: 430-432

14 Werber D, Fruth A, Liesegang A, et al. A multistate outbreak of Shiga toxin-producing Escherichia coli O26:H11 infections in Germany, detected by molecular subtyping surveillance. J Infect Dis, 2002, 186: 419-422

15 Brooks J T, Bergmire-Sweat D, Kennedy M, et al. Outbreak of Shiga toxin-producing Escherichia coli O111:H8 infections among attendees of a high school cheerleading camp. Clin Infect Dis, 2004, 38: 190198

16 Miyajima Y, Takahashi M, Eguchi H, et al. Outbreak of Enterohemorrhagic Escherichia coli O26 in Niigata City, Japan. Jpn J Infect Dis, 2007, 60: 238-239

17 Muraoka R, Okazaki M, Fujimoto Y, et al. An enterohemorrhagic Escherichia coli $\mathrm{O} 103$ outbreak at a nursery school in Miyazaki Prefecture, Japan. Jpn J Infect Dis, 2007, 60: 410-411

18 Schimmer B, Nygard K, Eriksen H M, et al. Outbreak of haemolytic uraemic syndrome in Norway caused by stx2-positive Escherichia coli $\mathrm{O} 103: \mathrm{H} 25$ traced to cured mutton sausages. BMC Infect Dis, 2008, 8: 41

19 Sonoda C, Tagami A, Nagatomo D, et al. An enterohemorrhagic Escherichia coli $\mathrm{O} 26$ outbreak at a nursery school in Miyazaki, Japan. Jpn J Infect Dis, 2008, 61: 92-93

20 Sekse C, O'Sullivan K, Granum P E, et al. An outbreak of Escherichia coli $\mathrm{O} 103: \mathrm{H} 25$-bacteriological investigations and genotyping of isolates from food. Int J Food Microbiol, 2009, 133: 259-264

21 Calderon V E, Chang Q, McDermott M, et al. Outbreak caused by cad-negative Shiga toxin-producing Escherichia coli O111, Oklahoma. Foodborne Pathog Dis, 2010, 7: 107-109

22 Piercefield E W, Bradley K K, Coffman R L, et al. Hemolytic uremic syndrome after an Escherichia coli O111 outbreak. Arch Intern Med, 2010, 170: 1656-1663

23 Lienemann T, Pitkanen T, Antikainen J, et al. Shiga toxin-producing Escherichia coli $\mathrm{O} 100: \mathrm{H}$ : stx2e in drinking water contaminated by waste water in Finland. Curr Microbiol, 2011, 62: 1239-1244

24 Nataro J P, Kaper J B. Diarrheagenic Escherichia coli. Clin Microbiol Rev, 1998, 11: 142-201

25 Phillips I, Eykyn S, King A, et al. Epidemic multiresistant Escherichia coli infection in West Lambeth Health District. Lancet, 1988, 1: 1038-1041

26 Unhanand M, Mustafa M M, McCracken G H, Jr, et al. Gramnegative enteric bacillary meningitis: A twenty-one-year experience. J Pediatr, 1993, 122: 15-21

27 Ochman H, Selander R K. Standard reference strains of Escherichia coli from natural populations. J Bacteriol, 1984, 157: 690-693

28 Pupo G M, Lan R, Reeves P R. Multiple independent origins of Shigella clones of Escherichia coli and convergent evolution of many of their characteristics. Proc Natl Acad Sci USA, 2000, 97: 1056710572

29 Yang J, Nie H, Chen L, et al. Revisiting the molecular evolutionary history of Shigella spp. J Mol Evol, 2007, 64: 71-79

30 Wirth T, Falush D, Lan R et al. Sex and virulence in Escherichia coli: An evolutionary perspective. Mol Microbiol, 2006, 60: 1136-1151

31 Touchon $M$, Hoede $C$, Tenaillon $O$, et al. Organised genome dynamics in the Escherichia coli species results in highly diverse adaptive paths. PLoS Genet, 2009, 5: e1000344

32 Mellmann A, Bielaszewska M, Kock R, et al. Analysis of collection of hemolytic uremic syndrome-associated enterohemorrhagic Escherichia coli. Emerg Infect Dis, 2008, 14: 1287-1290 
33 Bielaszewska M, Mellmann A, Zhang W, et al. Characterisation of the Escherichia coli strain associated with an outbreak of haemolytic uraemic syndrome in Germany, 2011: A microbiological study. Lancet Infect Dis, 2011, 11: 671-676

34 Bae W K, Lee Y K, Cho M S, et al. A case of hemolytic uremic syndrome caused by Escherichia coli O104:H4. Yonsei Med J, 2006, 47: 437-439

35 Frank C, Werber D, Cramer J P, et al. Epidemic profile of Shigatoxin-producing Escherichia coli O104:H4 outbreak in GermanyPreliminary Report. N Engl J Med, 2011, 365: 1771-1780

36 Scheutz F, Nielsen E M, Frimodt-Moller J, et al. Characteristics of the enteroaggregative Shiga toxin/verotoxin-producing Escherichia coli $\mathrm{O} 104: \mathrm{H} 4$ strain causing the outbreak of haemolytic uraemic syndrome in Germany, May to June 2011. Euro Surveill, 2011, 16

37 Rohde H, Qin J, Cui Y, et al. Open-source genomic analysis of Shigatoxin-producing E. coli O104:H4. N Engl J Med, 2011, 365: 718-724

38 Rasko D A, Webster D R, Sahl J W, et al. Origins of the E. coli strain causing an outbreak of hemolytic-uremic syndrome in Germany. N Engl J Med, 2011, 365: 709-717

39 Taormina P J, Beuchat L R, Slutsker L. Infections associated with eating seed sprouts: An international concern. Emerg Infect Dis, 1999, 5: 626-634

40 Brzuszkiewicz E, Thurmer A, Schuldes J, et al. Genome sequence analyses of two isolates from the recent Escherichia coli outbreak in Germany reveal the emergence of a new pathotype: Entero-AggregativeHaemorrhagic Escherichia coli (EAHEC). Arch Microbiol, 2011, 193: 883-891

41 Mellmann A, Harmsen D, Cummings C A, et al. Prospective genomic characterization of the german enterohemorrhagic Escherichia coli O104:H4 outbreak by rapid next generation sequencing technology. PLoS One, 2011, 6: e22751

42 Qin J, Cui Y, Zhao X, et al. Identification of the shiga toxinproducing Escherichia coli O104:H4 strain responsible for a food poisoning outbreak in germany by PCR. J Clin Microbiol, 2011, 49: 3439-3440

43 Smet A, Van Nieuwerburgh F, Vandekerckhove T T, et al. Complete nucleotide sequence of CTX-M-15-plasmids from clinical Escherichia coli isolates: Insertional events of transposons and insertion sequences. PLoS One, 2010, 5: e11202

44 Ogura Y, Ooka T, Iguchi A, et al. Comparative genomics reveal the mechanism of the parallel evolution of O157 and non-O157 enterohemorrhagic Escherichia coli. Proc Natl Acad Sci USA, 2009, 106: 17939-17944

45 Vica Pacheco S, Garcia Gonzalez O, Paniagua Contreras G L. The lom gene of bacteriophage lambda is involved in Escherichia coli K12 adhesion to human buccal epithelial cells. FEMS Microbiol Lett, 1997, 156: 129-132

46 Tarr P I, Bilge S S, Vary J C, Jr, et al. Iha: A novel Escherichia coli O157:H7 adherence-conferring molecule encoded on a recently acquired chromosomal island of conserved structure. Infect Immun, 2000, 68: 1400-1407

47 Savarino S J, Fox P, Deng Y, et al. Identification and characterization of a gene cluster mediating enteroaggregative Escherichia coli aggregative adherence fimbria I biogenesis. J Bacteriol, 1994, 176: 4949-4957

48 Kaper J B, Nataro J P, Mobley H L. Pathogenic Escherichia coli. Nat Rev Microbiol, 2004, 2: 123-140

Open Access This article is distributed under the terms of the Creative Commons Attribution License which permits any use, distribution, and reproduction in any medium, provided the original author(s) and source are credited.

\section{Supporting Information}

Table S1 List of strains that used in phylogenetic tree construction

Table S2 EHECs virulent-associated genes harbored in TY2482

The supporting information is available online at csb.scichina.com and www.springerlink.com. The supporting materials are published as submitted, without typesetting or editing. The responsibility for scientific accuracy and content remains entirely with the authors. 